\title{
Timing of Late Quaternary glaciations in the Himalayas of northern Pakistan
}

\author{
BENEDICT W. RICHARDS ${ }^{1}$, LEWIS A. OWEN ${ }^{2 *}$ and EDWARD J. RHODES ${ }^{3}$ \\ ${ }^{1}$ Department of Geography, Royal Holloway, University of London, Egham, Surrey TW20 0EX, England \\ ${ }^{2}$ Department of Earth Sciences, University of California, Riverside, CA 92521, USA \\ ${ }^{3}$ Research Laboratory for Archaeology and History of Art, Oxford University, 6 Keble Road, Oxford OX1 3QJ, England
}

Richards, B. W., Owen, L. A. and Rhodes, E. J. 2000. Timing of Late Quaternary glaciations in the Himalayas of northern Pakistan. J. Quaternary Sci., Vol. 15, pp. 283-297. ISSN 0267-8179.

Received 27 December 1998; Revised 8 October 1999; Accepted 13 October 1999

\begin{abstract}
Optically stimulated luminescence dating of Late Quaternary glaciogenic sediments was undertaken in critical areas of the Himalayas of northern Pakistan in order to examine the timing of glaciation. The dates demonstrate that several glaciations occurred during the last glacial cycle. In Swat, the Grabral 2 Stade and the Kalam I Stade were dated at ca. $77 \mathrm{ka}$ and ca. $38 \mathrm{ka}$, respectively. The error on the former date is large and it is conceivable that the moraines may have formed during the early part of Oxygen Isotope Stage 3 rather than during Oxygen Isotope Stage 4. The Kalam I Stade, however, clearly represents a glaciation during Oxygen Isotope Stage 3. The oldest moraines and those at the lowest altitude in the Indus valley at Shatial have an age of ca. $60 \mathrm{ka}$. These also relate to a major glacial advance during Oxygen Isotope Stage 3. A younger series of moraines, the Jalipur Tillite, and glaciofluvial sands at Liachar in the Indus valley, and moraines at Rampur-Tarshing have ages of ca. $27 \mathrm{ka}$, ca. 21-23 ka and ca. $15 \mathrm{ka}$, respectively. These dates show that glaciers also occupied parts of the Indus valley during Oxygen Isotope Stage 2. These dates and the morphostratigraphy show that glaciation in the Pakistani Himalaya was more extensive during the early part of the last glacial cycle and that the local last glacial maximum in Pakistan was asynchronous with the maximum extent of Northern Hemisphere ice sheets. Copyright (c) 2000 John Wiley \& Sons, Ltd.
\end{abstract}

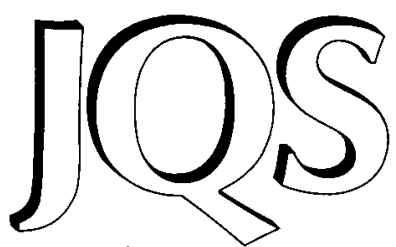

Journal of Quaternary Science

KEYWORDS: optically stimulated luminescence dating; Himalayas; Pakistan; moraines; glaciogenic sediments.

\section{Introduction}

Complex moraine ridges and valley fills, incised to depths of more than $100 \mathrm{~m}$, provide abundant evidence for multiple glaciation throughout the Himalayas of northern Pakistan (Porter, 1970; Derbyshire et al., 1984; Owen, 1988; Shroder et al., 1989; Scott, 1992). These sediments and landforms provide a useful record of the extent of glaciation throughout late Quaternary times in this high mountain region. Many of studies in this region, however, provide little sedimentological and geomorphological data to support their interpretation of ice limits and glacial reconstructions (e.g. Finsterwalder, 1935, 1937; Kick, 1986; Kuhle, 1986, 1996, 1997, 1998; Haserodt, 1989). Such data are important in assessing the validity of the conclusions of these papers and for accurate palaeoenvironmental reconstructions. This is particularly important because glacial and non-glacial diamictons are easily confused and misinterpreted in the high-energy

* Correspondence to: L. A. Owen, Department of Earth Sciences, University of California, Riverside, CA 92521, USA.

Email: Lewis.Owen@ucr.edu mountain environments of northern Pakistan (Owen, 1994). This has led to differing views on the extent of glaciers in valleys such as the middle Indus (cf. Kuhle, 1986, 1996, 1997, 1998; Haserodt 1989; Shroder et al., 1993). Some of the glacial reconstructions, for example, those by Kuhle (1986, 1996, 1997, 1998) are partially driven by modelling ice sheets rather than detailed field and laboratory analysis of landforms and sediments. Other researchers, such as $\mathrm{K}$. Haserodt (personal communication), are currently reassessing their glacial reconstructions based on recent fieldwork and reinterpretations of the sedimentology. Furthermore, little attempt has been made to date these sediments and landforms to help assess the timing of glaciation, and the magnitude and rates of environmental change. This is partially because dating moraines in high mountain environments is problematic owing to the general lack of organic material for the standard radiocarbon dating techniques and partially because of the logistical problems of access.

Derbyshire et al. (1984) provided the first preliminary thermoluminescence (TL) dates for northern Pakistan. These were for moraines in the Hunza valley in the Karakoram Mountains. Their paper, however, did not provide any descriptions of the dating procedures or data tables, and their dates had remarkably low errors given the large errors generally 
associated with TL dating of sediment, particularly those analysed in the early 1980s. The validity of their dates is, therefore, questionable. In the middle Indus valley, Shroder et al. (1989) provided TL dates on lacustrine sediments that overlay moraines. Only two of their dates, however, produced reasonable results. Owen et al. (1992) provided several TL dates on loess that overlies moraines in the Swat Himalaya. These dates provide minimum ages on glaciation because of the time lag between moraine formation and the onset of loess deposition. Furthermore, Owen et al. (1992) showed that the loess had been reworked by colluvial and pedogenic processes. This would make the dates on the loess considerably younger than the glaciation that formed the moraines. Recently, cosmogenic dating has been used in the Nanga Parbat Himalaya to provide some preliminary surface exposure dates on moraines to provide minimum ages for glaciation (Sloan, 1998).

In this paper, we will provide the first comprehensive set of optically stimulated luminescence (OSL) dates on glaciogenic sediments for the Himalayas of Pakistan. A variety of different types of OSL dating were undertaken on each sample to help test the reliability and validity of the dates. These data will help constrain the timing of glaciation in Pakistan. It will also help test Benn and Owen's (1998) hypothesis that glaciation throughout the Himalayas was asynchronous both regionally and with the Northern Hemisphere ice sheets. Furthermore, the data will help test contentious issues regarding the timing of the maximum extent of glaciation in the middle Indus valley, and they will provide ages for the Jalipur tillite, which is thought by Shroder et al. (1989) to be the oldest till in the Himalayas.

\section{Methods}

Four field areas were chosen where chronologies have already been developed by Porter (1970), Owen (1988), Shroder et al. (1989) and Scott (1992) (Fig. 1). Using the pre-existing geomorphological maps and the morphostratigraphies, sampling locations were chosen to constrain the timing of glaciation. Where necessary, the pre-existing geomorphological maps were modified to provide an improved morphostratigraphical framework. Sediments were examined in exposures in key landforms. Graphic sedimentary logs were constructed at these exposures and locations for OSL dating samples were chosen from appropriate sediment. Sampling was limited by the availability of exposures and lithologies at some locations. Each OSL dating sample was collected in an opaque plastic tube or as a large block that was wrapped in aluminum foil. The samples were immediately placed into a light-tight bag that remained sealed until opened under controlled laboratory lighting.

The OSL dating was undertaken at Royal Holloway, University of London. The course-grained quartz (90-125 $\mu \mathrm{m})$ fraction was prepared using the standard procedure of Rhodes (1988), with an additional step of 6-8 days immersion in concentrated fluorosilicic acid $\left(\mathrm{H}_{2} \mathrm{SiF}_{6}\right)$, following $\mathrm{HF}$ treatment. Standard preparation procedures for fine polymineral grains $(4-11 \mu \mathrm{m})$ were used following the methods of Zimmerman (1967). Several of the fine-grained samples were subsequently treated with $\mathrm{H}_{2} \mathrm{SiF}_{6}$ acid for 3-7 days to yield fine-grained quartz following the procedures of

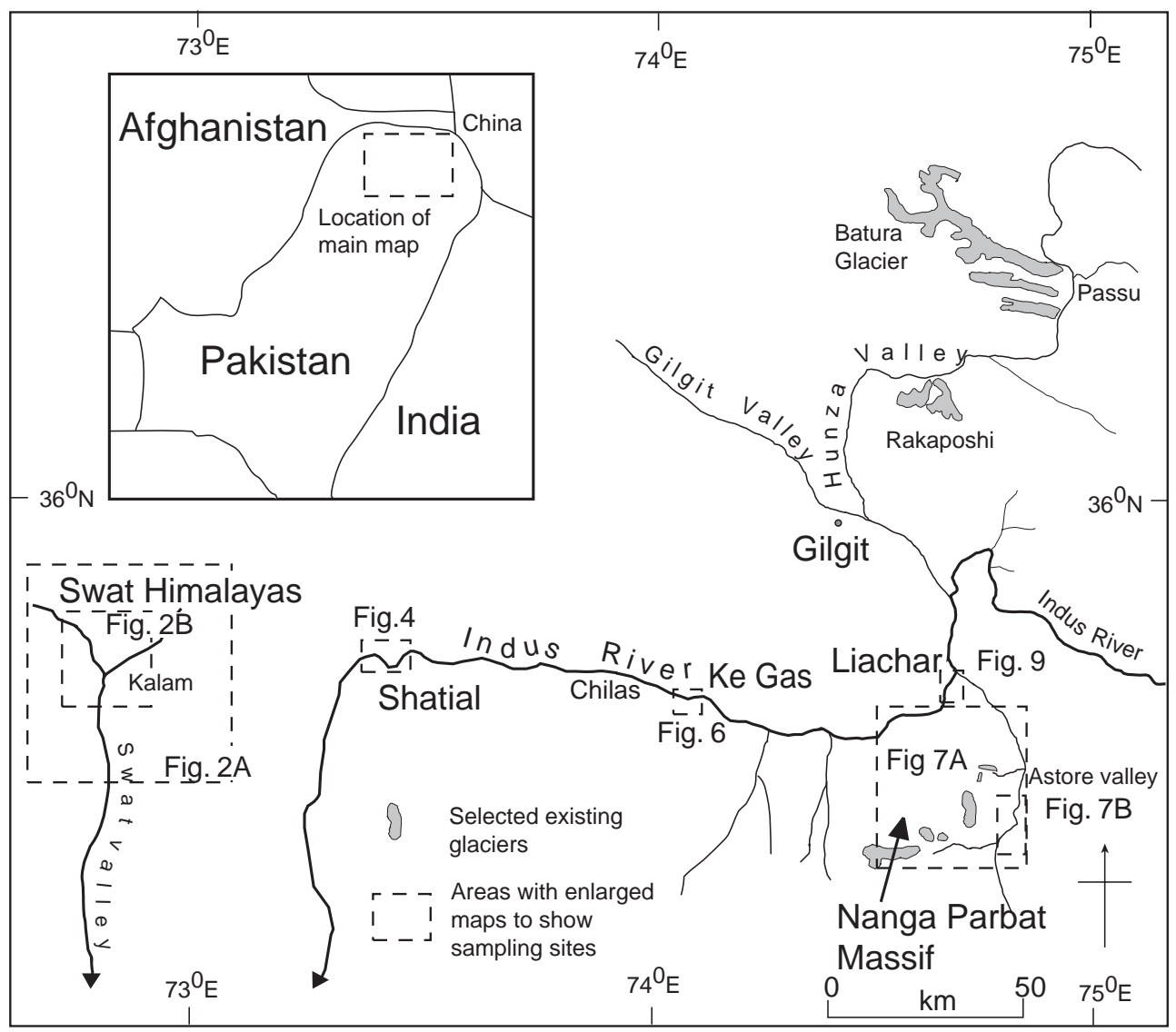

Figure 1 Map of northern Pakistan showing the study areas. The inset boxes refer to maps shown in subsequent figures. 

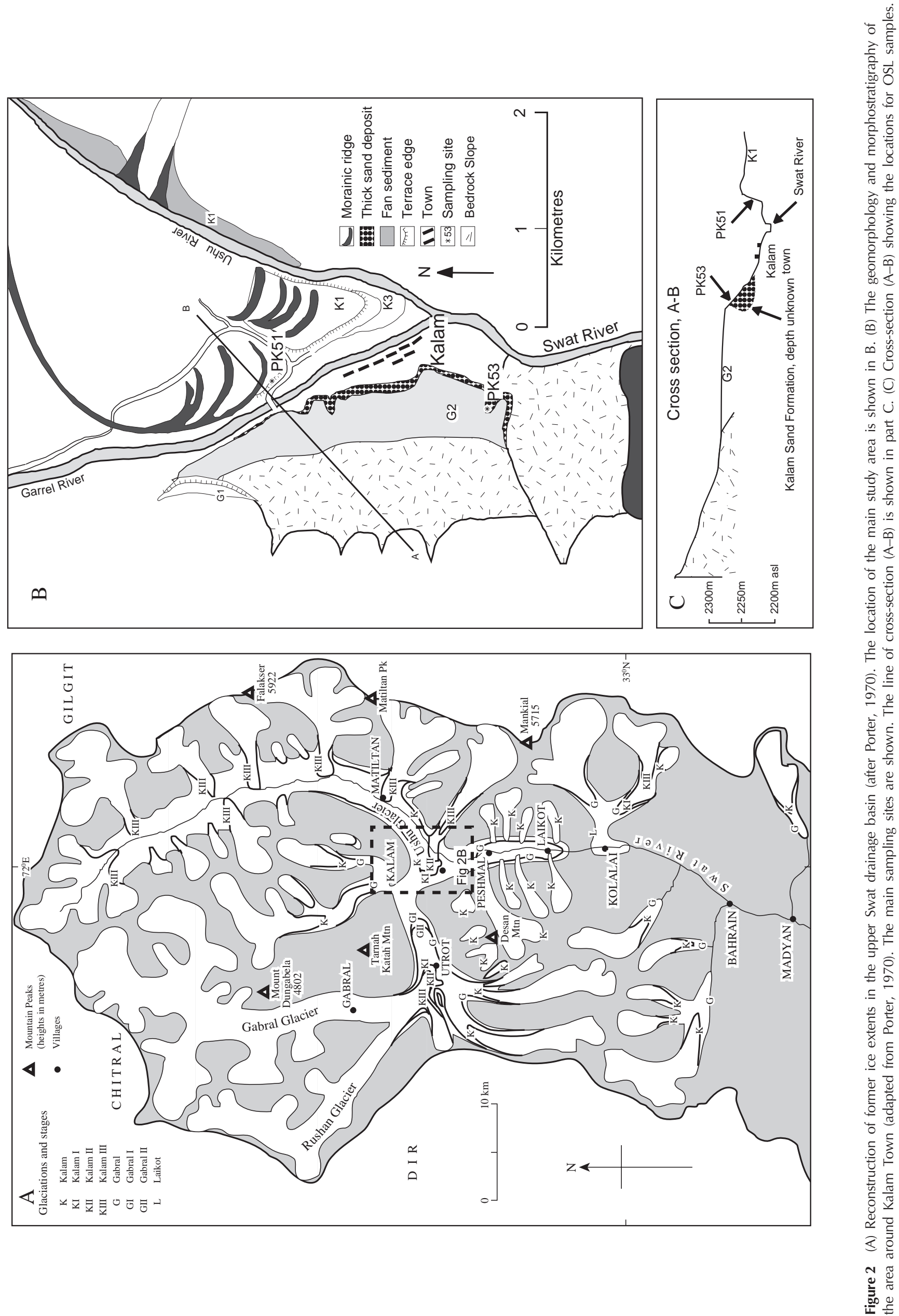
Table 1 TL dates for loess-like silts from Swat-from Owen et al. (1992)

\begin{tabular}{lrc} 
Sample location & $\begin{array}{l}\text { Additive dose method TL age } \\
(\mathrm{ka} \mathrm{BP})\end{array}$ & $\begin{array}{l}\text { Regenerative dose method TL } \\
\text { age }(\mathrm{ka} B P)\end{array}$ \\
\hline K1 terrace, top of covering silts & $5.88 \pm 0.53$ & $6.7 \pm 0.6$ \\
K1 terrace, base of covering silts & $1.95 \pm 0.20$ & $2.85 \pm 0.30$ \\
G2 terrace, top of covering silts & $19.71 \pm 2.20$ & $22.4 \pm 2.0$ \\
G2 terrace, base of covering silts & $14.36 \pm 1.49$ & $18.2 \pm 2.0$ \\
\hline
\end{tabular}

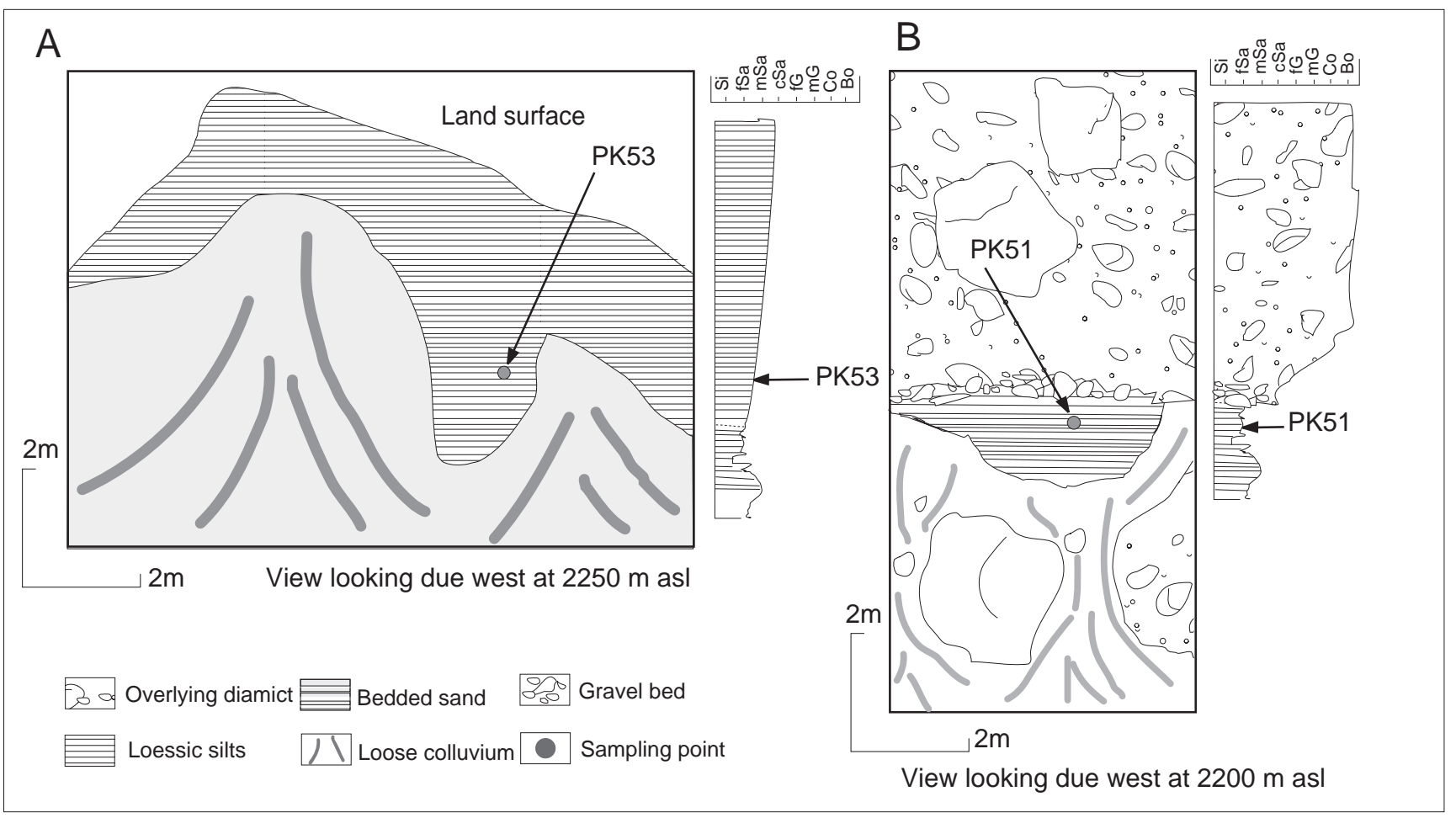

Figure 3 Sections and graphic sedimentary logs showing the sampling positions for: $(A)$ PK53 and (B) PK51. Si = silt; fSa = fine sand; mSa $=$ medium sand; $\mathrm{cSa}=$ coarse sand; $\mathrm{fG}=$ fine gravel; $\mathrm{mG}=$ medium gravel; $\mathrm{Co}=$ cobbles; $\mathrm{Bo}=$ boulders .

Rees-Jones (1995). Polymineralic and quartz fine grains were settled on to aluminum discs from acetone.

All luminescence measurements were made using an automated Risø reader, TL-DA-12, fitted with infrared emitting diodes providing stimulation at $880 \Delta 80 \mathrm{~nm}$ and a filtered halogen lamp as a green light source, which provides broad band stimulation between 420 and $560 \mathrm{~nm}(2.9-2.2 \mathrm{eV}$ ). Emissions were filtered with $5 \mathrm{~mm}$ Hoya U340 and $1 \mathrm{~mm}$ Schott BG39 glass filters. This arrangement optimises the detection of luminescence from quartz.

All equivalent dose $\left(D_{\mathrm{E}}\right)$ values were determined using a naturally normalised total integral, multiple aliquot additive dose technique, fitting a single saturating exponential function. Twenty-four to forty-eight aliquots were measured at eight dose points, with the maximum additional beta dose being four to five times the preliminary $D_{\mathrm{E}}$ value. Subtraction of the background luminescence signal was by the last integral subtraction method (Aitken and Xie, 1992). The preheat treatment used for all quartz subsamples was $220^{\circ} \mathrm{C}$ for $5 \mathrm{~min}$ and for polymineral samples was 5 days at $100^{\circ} \mathrm{C}$ followed by $4 \mathrm{~h}$ at $160^{\circ} \mathrm{C}$. Measurement of all subsamples was carried out, both infrared (IRSL) and green light (GLSL) stimulation for $50 \mathrm{~s}$ at room temperature. In the case of polymineralic samples, IRSL measurement preceded OSL measurement using the same aliquots.

The magnitude of a thermal transfer component in the quartz GLSL signal (Rhodes and Bailey, 1997) was determined using a regenerative $x$-axis intercept. In all cases, the magnitude of the thermal transfer signal was found to be insignificant. Fading tests for IRSL and GLSL were carried out on most of the subsamples measured, and showed no discernible fading over a 10-day period. Longer term anomalous fading cannot be ruled out for the polymineral subsamples. Where multiple $D_{\mathrm{E}}$ values were measured for the fine-grained samples (both quartz and polymineralic fractions), the measurements were combined to produce a weighted mean $D_{\mathrm{E}}$ value.

The environmental dose rate was calculated from neutron activation analysis of the $U$, Th and $K$ content of each sample. The cosmic dose rate was calculated according to Prescott and Hutton (1994), based on the present-day depth of overburden and the latitude and altitude of each sample location. The water content measured for each sample was used to calculate environmental radiation attenuation during burial using the methods of Zimmerman (1971). 

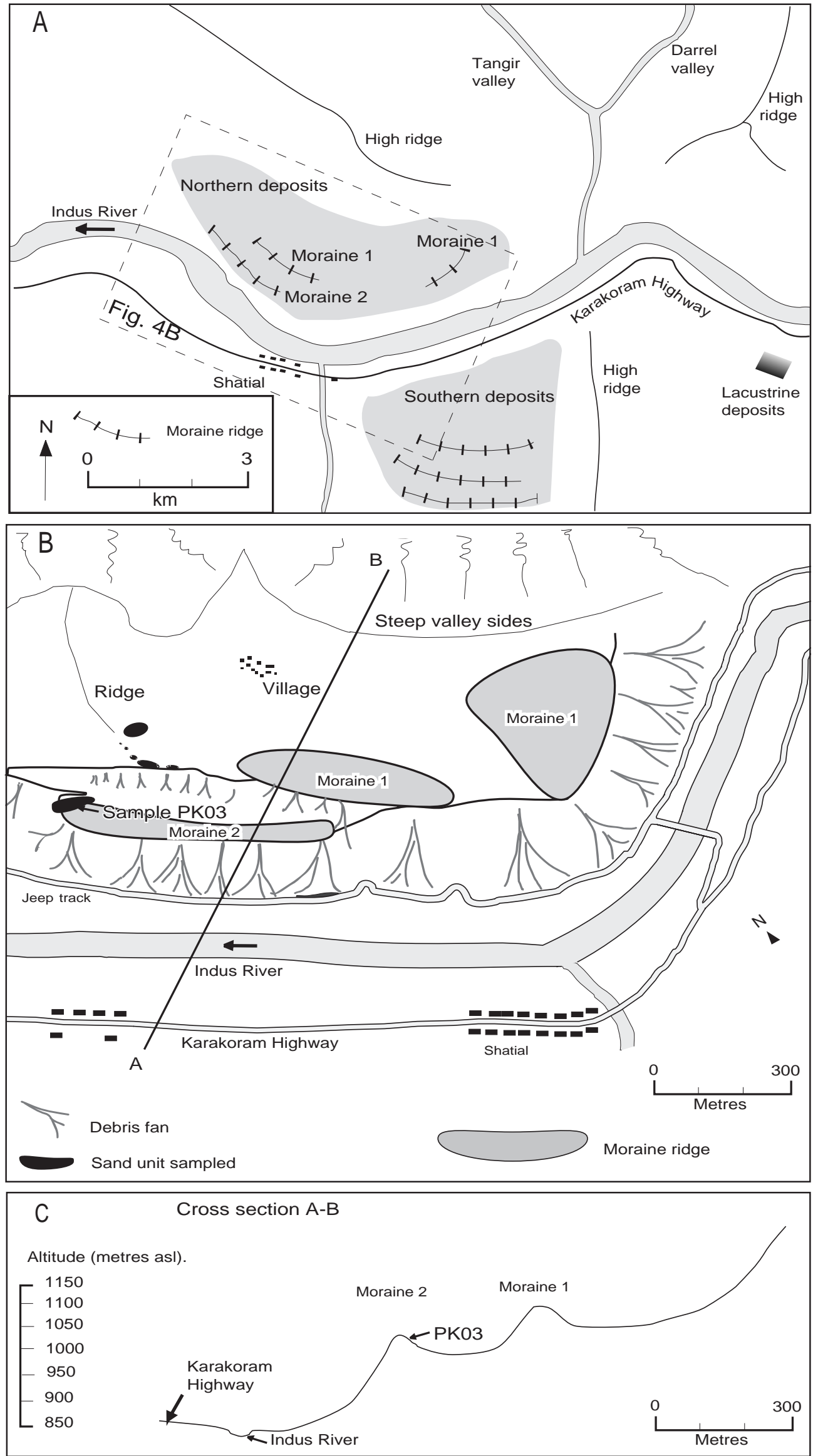

Figure 4 (A) Simplified geomorphological map of the area around Shatial showing the main moraines; (B) detailed map of the study area showing the location of the sampling site for PK03. The line of cross-section (A-B) is shown in part C. (C) Cross-section (A-B) showing locations for OSL dating sample. 
Table 2 TL dates for glaciolacustrine sediments from the IndusGilgit region-from Shroder et al. (1989)

\begin{tabular}{lll}
\hline & $\begin{array}{l}\text { Shroder et al.'s } \\
\text { relative age }\end{array}$ & $\begin{array}{l}\text { TL age } \\
(\mathrm{ka} \mathrm{BP})\end{array}$ \\
\hline $\begin{array}{l}\text { Gilgit-Hunza River } \\
\text { confluence }\end{array}$ & $\begin{array}{l}\text { Middle } \\
\text { Last Glaciation } \\
\text { Sazin }\end{array}$ & $31.4 \pm 2.0$ \\
Siddle & $38.1 \pm 2.6$ \\
Last Glaciation & $\begin{array}{l}\text { Early } \\
\text { Last Glaciation } \\
\text { Gilgit }\end{array}$ & $>40$ \\
& $\begin{array}{l}\text { Post Late } \\
\text { Middle Glaciation }\end{array}$ & \\
\hline
\end{tabular}

\section{Swat Himalaya}

Landforms in the upper Swat Valley provide evidence for three major glaciations (Fig. 2A), together with several recent localised advances (Porter, 1970). These comprise moraine ridges and associated outwash terraces. These are capped by loess deposits, which Porter (1970) showed are thickest on the oldest landforms. The oldest glaciation, the Laikot Glaciation, is represented by isolated and highly weathered till remnants above the town of Kalam and the U-shaped nature of the valleys south of Laikot village. The second glaciation, the Gabral Glaciation, produced two levels of terraces on the western side of the valley at Kalam, and a diamiction deposit in the Garrel valley. Porter (1970) divided this glaciation into early and late stades (Gabral I and Gabral II). The most recent large-scale glaciation, the Kalam Glaciation, is represented by numerous concentric moraine ridges on the eastern side of the Garrel River north of Kalam (Fig. 2A and B). Porter (1970) divided these moraine ridges into early, intermediate and late stades (Kalam I, Kalam II and Kalam III) and correlated each stade with fluvial terraces in the Kalam area.

At Kalam, a thick (>30 m) deposit of well-sorted, evenly bedded sand forms a particularly impressive landform and is stratigraphically important. Rocks derived from the mountain front west of Kalam dominate its lithology. Porter (1970) suggested that this sediment was deposited as a delta by a tributary stream that fed into a lake. The origin of the dam is unclear, but Porter (1970) suggested that it might have formed when a side valley glacier advanced and blocked the main valley. The deltaic sediments are clearly older than the outwash of the Gabral II terrace that overlies it. Its relationship with the earlier Gabral I glaciation, however, is unclear but Porter (1970) suggests that it was probably deposited after the dissection of the Gabral I valley floor. In this paper, these deltaic sands are named the Kalam Sand Formation.

Owen et al. (1992) examined the sedimentology of loessic silt deposits that overlie the glacial landforms and they used TL dating to provide minimum ages for their formation (Table 1). On the basis of sedimentological evidence, they showed that the silts have been reworked by slope processes and emphasised that the TL ages are younger than any reasonable estimates of the age of the glaciations in the Kalam region. Furthermore, they concluded that great care must be taken when using loessic sediments for dating Quaternary events in high-energy environments.

Sampling for OSL dating was undertaken in the area around the town of Kalam (2200 m a.s.l.) to test the validity of the dates quoted in Owen et al. (1992) and constrain the glacial history in this region.

A thorough search was undertaken for glaciogenic sediments of Laikot glacial age. Unfortunately, it was not possible to find any appropriate sampling locations because of recent farming activities and afforestation. In particular, there was no evidence of the ' $10 \mathrm{ft}$ of bluish to greenish-gray sands and clay containing scattered pebbles' that Porter (1970, p. 1434) described on the slopes high above the Kalam valley.

The Kalam Sand Formation, however, was exposed at the southern end of Kalam in an 8-10 $\mathrm{m}$ high face in a sand and gravel pit (Figs 2C and 3). If Porter (1970) is correct in asserting that the valley was blocked by an advancing glacier, causing a lake and delta (comprising the Kalam Sand Formation) to form, then the date could also indicate the time of a glacial advance. Figure $2 \mathrm{C}$ shows the location of sample PK53 that was collected from 1-2 cm thick planar beds of fine to medium sand. A date on the Kalam Sand Formation should antedate the G2 glacial stage, and would probably post-date the G1 glaciation.

The Kalam moraines were sampled in an exposure in a road cut just south of the main road bridge at Kalam (Fig. 2B). Here, a 3-m-high exposure is present within a Kalam 1 moraine. The moraine comprises diamict units containing boulders up to $1 \mathrm{~m}$ in diameter supported by a matrix of

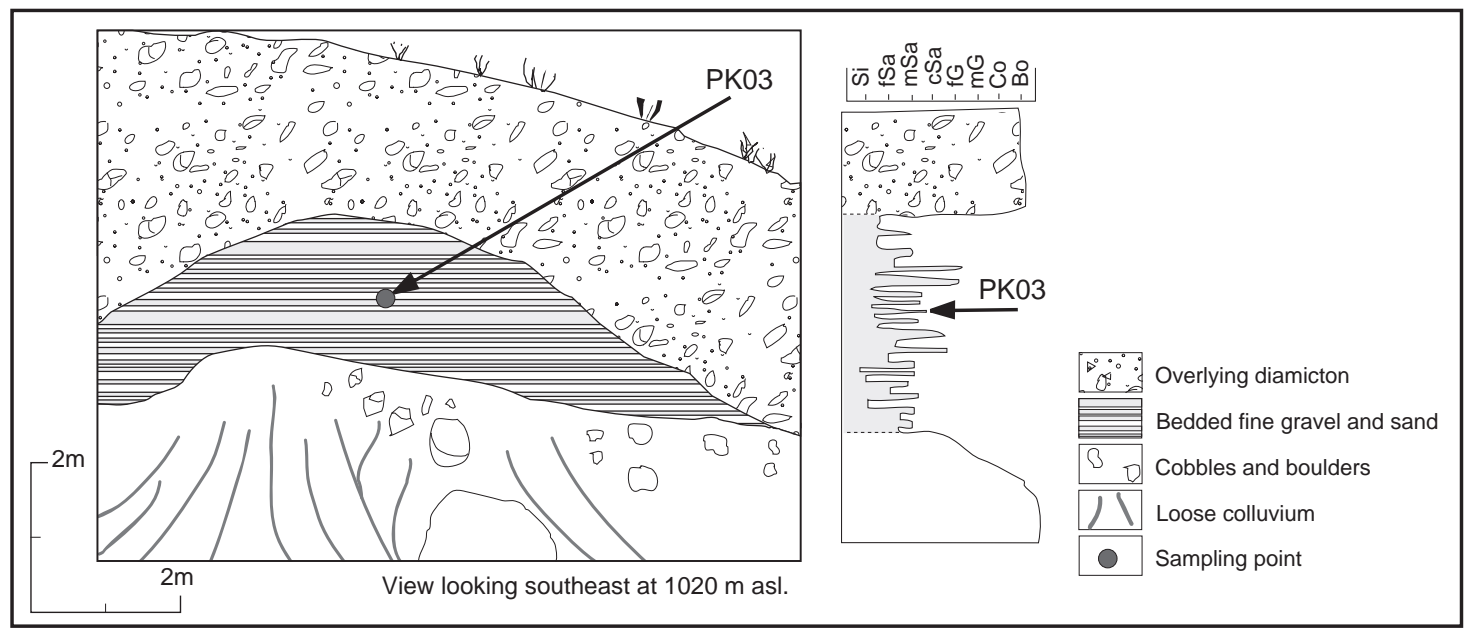

Figure 5 Section and graphic sedimentary log showing the sampling position for PK03. Si = silt; fSa = fine sand; mSa = medium sand; cSa $=$ coarse sand; $\mathrm{fG}=$ fine gravel; $\mathrm{mG}=$ medium gravel; $\mathrm{Co}=$ cobbles; $\mathrm{Bo}=$ boulders . 
unsorted sand and silt-sized material (Fig. 3). Several small units of bedded sand are intercalated with the diamict units. Sample PK51 was collected from a $50 \mathrm{~cm}$ thick unit of bedded sand. This unit is overlain by a diamict unit ca. $4.5 \mathrm{~m}$ thick. A date from this location would directly date the $\mathrm{K} 1$ glacial maximum.

\section{Shatial}

The village of Shatial is only $850 \mathrm{~m}$ a.s.I., yet it is surrounded by impressive moraines (Fig. 4A). Owen (1988) and Shroder et al. $(1989,1993)$ have considered this location. They mark this location as the maximum extent and lowest elevation of glaciation in the Indus catchment. There is still much debate, however, as to whether these moraines where formed by a main Indus valley trunk glacier or from tributary valley glaciers (cf. Kuhle, 1986, 1997, 1998). Clearly, an age on these landforms is important in the evaluation of the palaeoclimate of this region.

Downstream of Shatial, the Indus valley comprises a deep, narrow, steep sided, V-shaped gorge, whereas upstream of Shatial, the valley is broad and U-shaped. This helps support the view that glaciers did not extend down the Indus valley much beyond Shatial. Furthermore, no moraines are present along the Indus valley west of Shatial. At Shatial the large moraines are dissected and incised to depths of more than $200 \mathrm{~m}$ (Fig. 4). On the basis of morphology and morphostra-
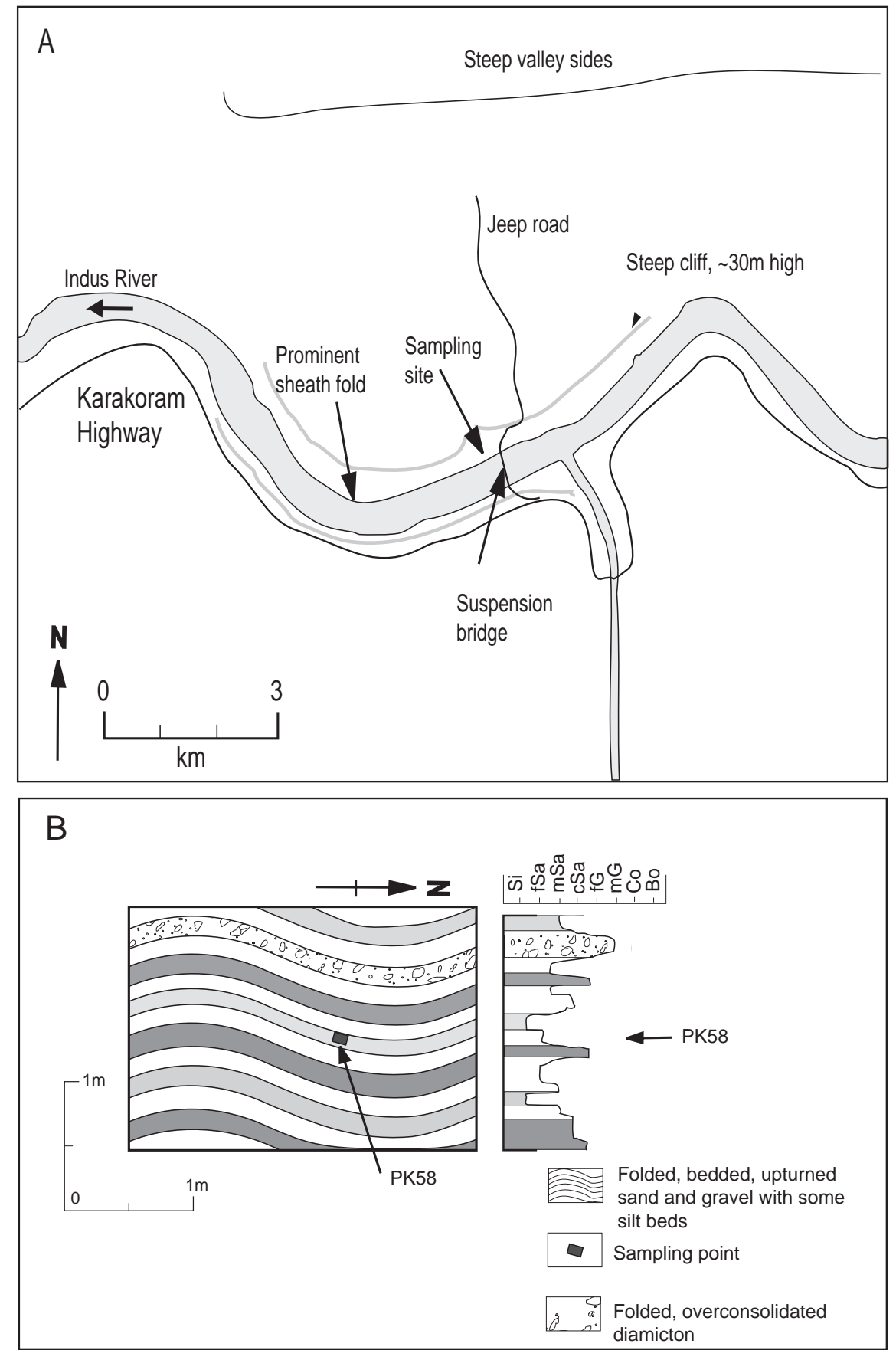

Figure 6 (A) Map showing the location of Ke Gas sheath fold and the sampling location. (B) Detailed map and graphic sedimentary log showing the location where PK58 was sampled. $\mathrm{Si}=$ silt; $\mathrm{fSa}=$ fine sand; $\mathrm{mSa}=$ medium sand; $\mathrm{cSa}=\mathrm{coarse}$ sand; $\mathrm{fG}=\mathrm{fine}$ gravel; $\mathrm{mG}=$ medium gravel; $\mathrm{Co}=$ cobbles; Bo = boulders. 

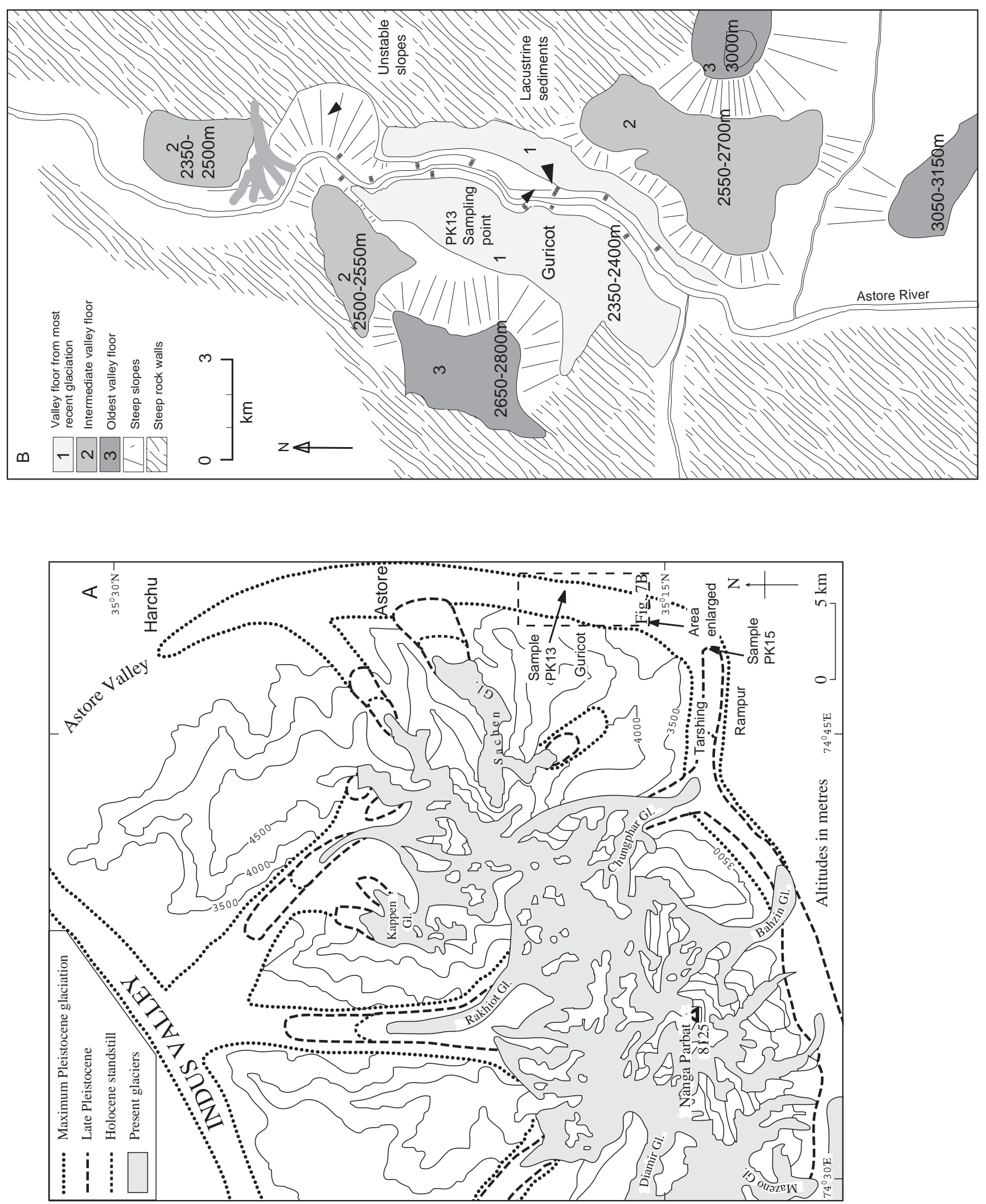
tigraphy, the landforms and deposits on the southern side of the valley were considered by Shroder et al. (1989) to be terminal moraines. They considered these to have formed when a glacier originating in the Darrel and Tangir valleys and possibly converging with the main Indus valley glacier ca. $3 \mathrm{~km}$ east of Shatial, flowed down the main Indus valley. They interpreted these southern deposits to be of younger age than landforms and deposits on the northern side of the Indus valley. They believed the main Indus valley trunk glacier produced these landforms. The northern deposits, therefore, would provide an age for the maximum extent of glaciation for the Indus catchment. Figure 4 ( $B$ and $C$ ) shows the geomorphology of the deposits and landforms north of Shatial. These comprise two distinct moraine ridges comprising well-cemented diamict units. These ridges trend subparallel to the main Indus valley and are topped by bedded coarse sands and gravels that dip northwards.

Deposits of well-consolidated laminated lacustrine silts are present upstream of Shatial, on the sides of the Indus valley. These occur intermittently for about $60 \mathrm{~km}$ up-valley. The top of this deposit is at ca. $1000 \mathrm{~m}$ a.s.l. These lacustrine deposits show that the Indus valley, upstream of Shatial, was dammed to form a lake at a height of ca. $1000 \mathrm{~m}$ a.s.l. It is not clear what caused the dam, but moraine ridge 2 (Fig. 4) at Shatial is at the same elevation as the uppermost lacustrine sediments. This suggests that the formation of the two features may be related and that the lacustrine sediments formed when a glacier advanced into the Indus valley. Their high elevation above the present river level and the intense incision suggests that they were probably deposited a considerable time ago and subsequently deeply eroded. Shroder et al. (1989) published a TL date of $38.1 \pm 2.6 \mathrm{ka}$ for these sediments (Table 2). They also quoted an alternative date of $56 \mathrm{ka}$ (no error quoted) when calculated with water content at $75 \%$ of saturation instead of the water content as found (i.e., in situ). Unfortunately, the exact location of the landforms and sediments that were sampled were not described.

The northern moraine ridges resemble contemporary lateral moraines rather than terminal moraines (cf. Owen, 1988, 1994; Hewitt, 1989; Owen and Derbyshire, 1989; Scott, 1992). Such an interpretation would be consistent with either a main trunk valley glacier or a tributary valley glacier flowing into the Indus valley. The lacustrine sediments that are present upstream and at the same elevation as the top of moraine 2 may have been deposited in a lake dammed by the glacier that formed moraine 2 . This would virtually exclude the possibility of the moraine being formed by a trunk glacier in the main Indus valley, because a lake would have occupied the main Indus valley at this time. Nevertheless, these moraines clearly represent the lowest elevation of moraines in the Indus catchment.

Sample PK03 was collected from a stream cutting the western end of moraine ridge 2 (Figs 4 and 5). The exposure comprises a unit of planar bedded sand and fine gravel ca. $3 \mathrm{~m}$ thick, sandwiched between matrix-supported diamict composed of coarse gravel, cobbles and boulders in a matrix of sands and silts (Fig. 5).

The sediments are interpreted as ice-marginal facies that comprised a lateral or a latero-terminal moraine complex. The sand was probably deposited by an ice marginal stream, and was subsequently overlain by diamict units that are interpreted to be supraglacial in origin. A date from PK03 would, therefore, provide an age close to the last time that ice resided in this part of the Indus valley.

\section{Ke Gas}

Deformed overconsolidated and lithified deposits of diamicts are present rising to elevations of between 100 and $350 \mathrm{~m}$ above the contemporary river along numerous stretches of the middle Indus valley. Misch (1935) called these sediments the Jalipur Tillite and Owen $(1988,1989)$ and Shroder et al. (1989) have confirmed their glacial origin. On the basis of their consolidation and lithification, Shroder et al. (1989) believed these sediments to represent the oldest tills in the Himalayas. He argued that they had been down faulted to their present positions. Owen (1988, 1989), however, interpreted their sedimentology and structures to represent glaciotectonised sediments of a much younger age. Dating the Jalipur Tillite is important in resolving whether these sediments provide evidence for the earliest glaciation in

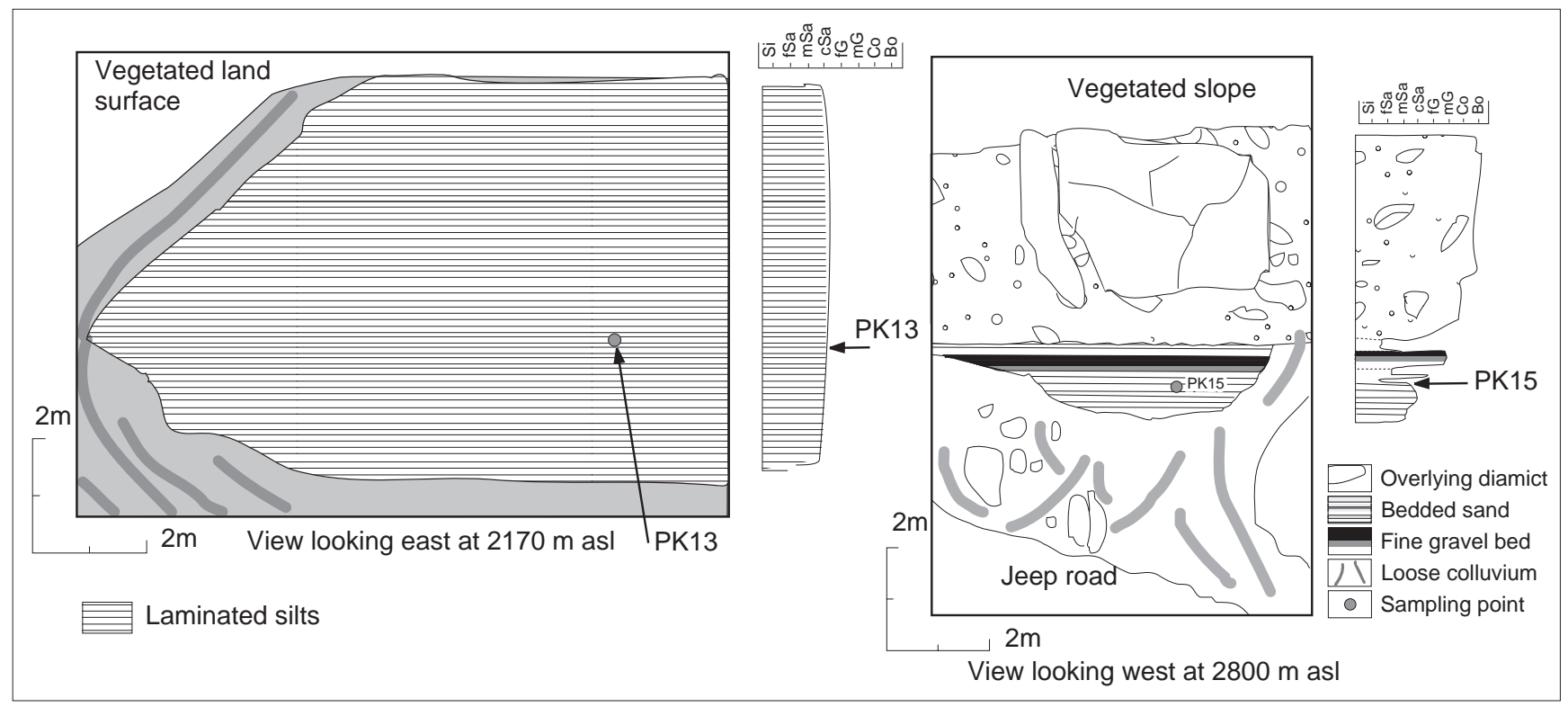

Figure 8 Sections and graphic sedimentary log showing the sampling position for PK13 and PK15. Si = silt; fSa = fine sand; mSa = medium sand; $\mathrm{cSa}=$ coarse sand; $\mathrm{fG}=$ fine gravel; $\mathrm{mG}=$ medium gravel; $\mathrm{Co}=$ cobbles; Bo $=$ boulders. 

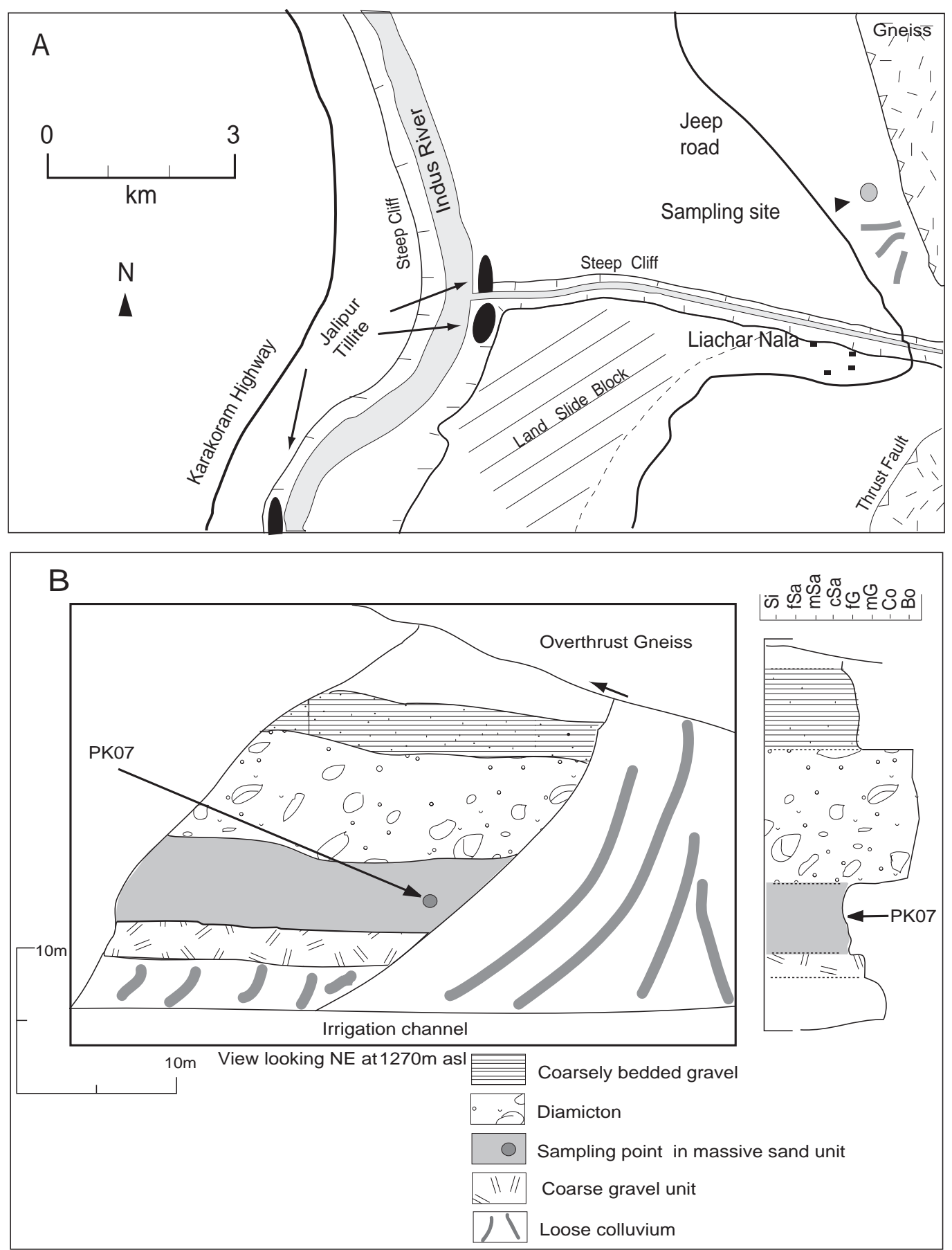

Figure 9 (A) Map showing the sampling location and (B) sections and graphic sedimentary log for PK07. Si = silt; fSa = fine sand; $\mathrm{mSa}=$ medium sand; $\mathrm{cSa}=$ coarse sand; $\mathrm{fG}=$ fine gravel; $\mathrm{mG}=$ medium gravel; $\mathrm{Co}=$ cobbles; Bo = boulders.

northern Pakistan or if they represent a main valley glaciation that occurred during the late Quaternary.

The Jalipur Tillite is best exposed at Ke Gas (Fig. 6A) where diamict units (tillite) and associated glaciofluvial and lacustrine silts, sands and gravels are folded into complex structures that constitute a major sheath fold (Owen, 1988, 1989). Sample PK58 was collected from a deformed consolidated silt bed that overlies the diamict units on the right bank of the Indus ca. $200 \mathrm{~m}$ downstream of the Ke Gas suspension bridge (Fig. 6B).

\section{Nanga Parbat}

A comprehensive modern study of the glacial geology of Nanga Parbat was undertaken by Scott (1992) and summa- rized in Derbyshire and Owen (1997) and Owen et al. (2000). On the basis of geomorphological and sedimentological evidence, Scott (1992) showed that two major glaciations and a later minor glacial advance had occurred in the Astore valley (Fig. 7A). She also argued that truncated spurs, overdeepened trunk valleys and steep valley sides provided evidence for an even earlier extensive glaciation.

Near Guricot in the Astore valley, Scott (1992) described glaciolacustrine deposits that formed during a period of deglaciation at the end of the last main valley glaciation. These deposits comprise a unit of horizontally bedded medium and fine sands $>100 \mathrm{~m}$ thick. She believed they were deposited when a glacier during deglaciation blocked the main valley. A date on this sediment would constrain the timing of deglaciation. Alternatively, this stretch of the valley is an area of extreme slope instability and it may be 
likely that a mass movement deposit blocked the valley to form a lake. If the latter interpretation is true, then a date from this sediment would have little glacial significance. Sample PK13 was collected from an exposure opposite Guricot village (Fig. 7B). The sample comprised a horizontal planar bed of fine sand $12 \mathrm{~cm}$ thick (Fig. 8).

In Rampur valley on the southern side of the Nanga Parbat massif, Scott (1992) described hummocky landforms that comprised thick diamict units that are interpreted as meltout tills. Throughout these deposits the clasts show similar degrees of weathering. Scott (1992) believes that this indicates that the glacial retreat was relatively rapid. The surface of the landform is broadly level but uneven, with small round depressions. At its eastern end along the eastern and northern sides, the landform has been incised by the Astore Fluss River to produce a 13-16-m-high exposure transversed by a road cutting. Here the sediments comprise diamict units that sandwich sands and gravels (Fig. 7A). Sample PK15 was collected from gently dipping $\left(<5^{\circ}\right)$ fine sand (Fig. 8). This sediment is interpreted as ice-contact glaciofluvial in origin. A date from this location would, therefore, constrain the age of a glacial retreat from this location in the Tarshing valley.

At Liachar, ca. $5 \mathrm{~km}$ upstream of Rakhiot bridge, Owen (1989) described an impressive neotectonic thrust, the Liachar thrust (Fig. 9A). Here, Nanga Parbat gneiss is thrust over Quaternary sediments (Fig. 9A and B). On the basis of sedimentological characteristics, Owen (1989) interpreted these sediments as glaciofluvial in origin and he believed them to be late Pleistocene in age. Dating these deformed glaciofluvial sediments may provide a deglaciation age for the last major trunk valley glacier in the Indus valley and it would provide data to help reconstruct rates of neotectonic faulting. Sample PK07 was taken from these glaciofluvial deposits (Fig. 9B). A block sample was removed from a 3m-thick unit of slightly consolidated well-sorted and massive sand that overlies a 4-m-thick coarse gravel unit.

\section{Dating results}

The OSL dating results are shown in Table 3 and Figure 10. When particle-size and mineral yield were sufficient, a variety of different methods was used, as described above, to check the reliability and validity of the age of each sample. The successful methods, that is, those where the sensitivity was sufficiently high and where there was no mineral contamination, are shown in Table 3.

Analysis of the fine-grained polymineralic (FGPM), finegrained quartz (FGQ) and coarse-grained quartz (CGQ) on PK03 all yielded ages. The coarse- and fine-grain analysis, however, are in disagreement. The CGQ measurements produced an age of $20.0 \pm 3.1 \mathrm{ka}$, whereas the FGQ result was $61.0 \pm 9.7 \mathrm{ka}$ and the FGPM was $54.6 \pm 8.6 \mathrm{ka}$ for the GLSL method and $51.1 \pm 7.4 \mathrm{ka}$ for the IRSL method (GLSL and IRSL for FGPM were measured from the same discs). The fact that the two differently prepared fine-grained subsamples agree well with each other and that the GLSL and IRSL of the FGPM agree internally is considered significant. The disagreement between fine-grained subsamples and the CGQ is probably because the latter subsample had non-quartz contamination, as the CGQ had high IRSL values and TL glow curve shapes. Therefore the age given by this subsample is considered less reliable than the ages given by the fine-grained samples. Using the GLSL results from the
FGPM and FGQ, a weighted mean of the two subsamples was calculated to give an age of $59.1 \pm 8.5 \mathrm{ka}$.

Only GLSL was measured on CGQ for PK13, PK15 and PK53, giving ages of $3.3 \pm 0.58 \mathrm{ka}, 15.1 \pm 4.4 \mathrm{ka}$ and 77.2 $\pm 18.1 \mathrm{ka}$, respectively.

Both GLSL and IRSL were measured on FGPM for PK07, which produced ages of $22.6 \pm 3.4 \mathrm{ka}$ and $20.6 \pm 3.0 \mathrm{ka}$, respectively. Both these ages agree well and have overlapping errors.

The GLSL method on FGQ and FGPM and the IRSL method on FGPM produced ages for PK51. All the results are within one standard deviation error of each other. The GLSL $D_{\mathrm{E}}$ values from FGPM have been combined with those from FGQ to give a weighted mean of $37.9 \pm 10.3 \mathrm{ka}$.

Both the GLSL, on FGPM and FGQ, and IRSL, on FGPM, methods were used to date PK58. A weighted mean of the GLSL results for both the FGQ and the FGPM was calculated, resulting in an age estimate of $27.0 \pm 4.3 \mathrm{ka}$. This is considered the most credible result from the analysis of this sample, because it contains data from two distinct mineralogies, with different bleaching rates and dose values, and is derived from a total of 96 aliquots of sample. It is, therefore, considered to be more reliable than any of the figures derived separately.

\section{Discussion and conclusions}

The OSL dates indicate that all the glaciogenic sediments that were examined in this study formed during the last glacial cycle. Furthermore, the ages indicate that several glaciations occurred during the last glacial cycle, each becoming progressively less extensive with time.

In Swat, the Grabral 2 Stade has an age of ca. $77 \mathrm{ka}$, corresponding to Oxygen Isotope Stage 4. The error on this date, however, is large and it is conceivable that the moraines may have formed during the early part of Oxygen Isotope Stage 3. The Kalam 1 moraines in Swat have an age of ca. $38 \mathrm{ka}$ and they clearly represent a glaciation during Oxygen Isotope Stage 3. The oldest moraines and those at the lowest altitude in the Indus valley are present in the Shatial area and have an age of ca. $60 \mathrm{ka}$. These probably relate to a major glacial advance during Oxygen Isotope Stage 3. These dates and the morphostratigraphy show that glaciation in the Pakistan Himalaya was more extensive during the early part of the last glacial cycle.

Glaciers also occupied parts of the Indus valley during Oxygen Isotope Stage 2, as supported by the ca. $27 \mathrm{ka}$ age on the Jalipur Tillite in the Indus valley and the ages on the moraines at Rampur-Tarshing (ca. $15 \mathrm{ka}$ ) and the glaciofluvial sands at Liachar (ca. 21-23 ka). This glaciation, however, was much more reduced in extent than the previous glaciation and the later two dates may represent glaciers in a state of retreat.

These OSL ages are supported by the cosmogenic dates obtained by Sloan et al. (1998) for the Nanga Parbat region. They showed that glaciers advanced at least twice during the last glacial cycle, and two glaciations occurred during Oxygen Isotope Stage 3 at ca. $56 \mathrm{ka}$ and ca. $35 \mathrm{ka}$. Given the errors associated with both dating techniques, the overlap of ages is reasonable and suggests that at least one major glaciation occurred during Oxygen Isotope Stage 3 in the Himalayas of Pakistan.

The OSL dates also show that Owen et al.'s (1992) TL dates on loess deposits on top of moraines in the Kalam 


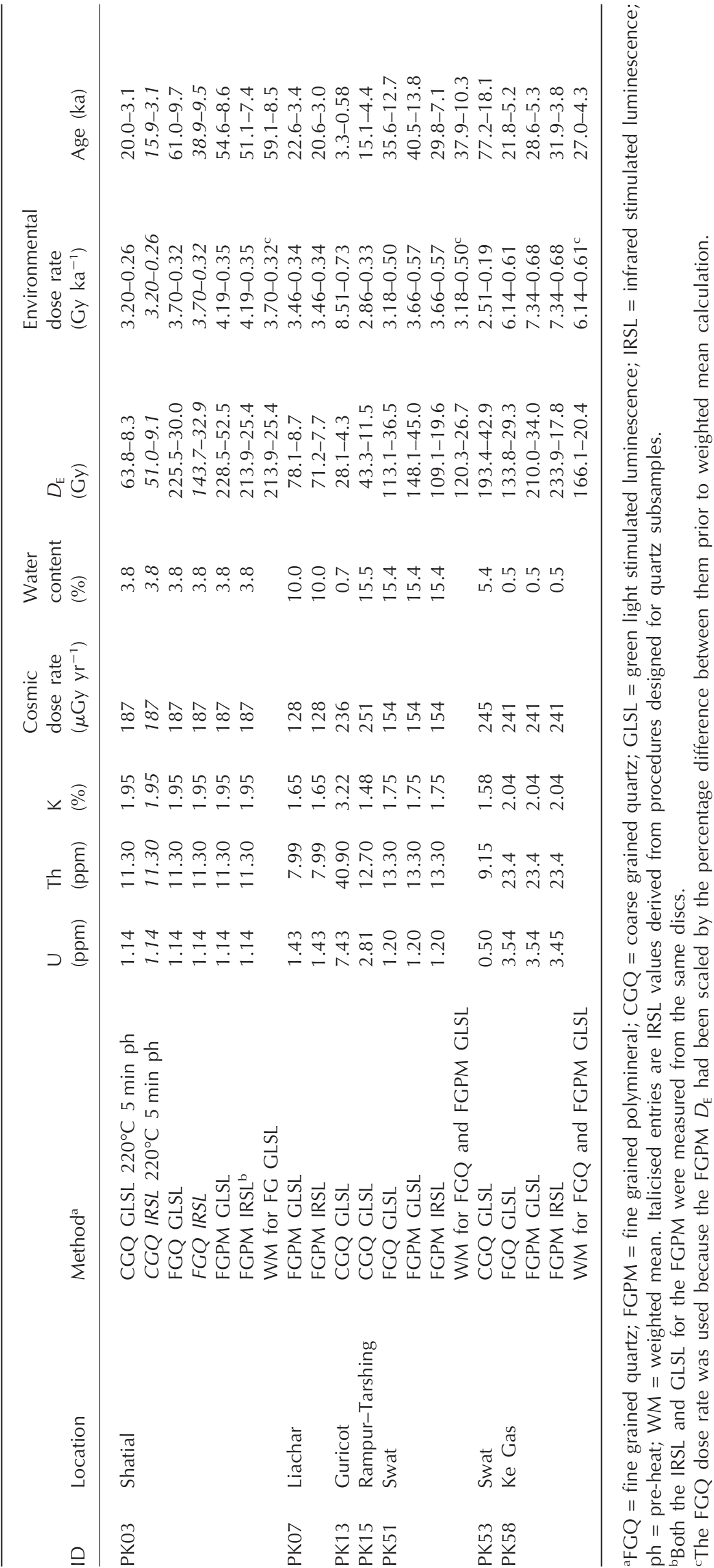




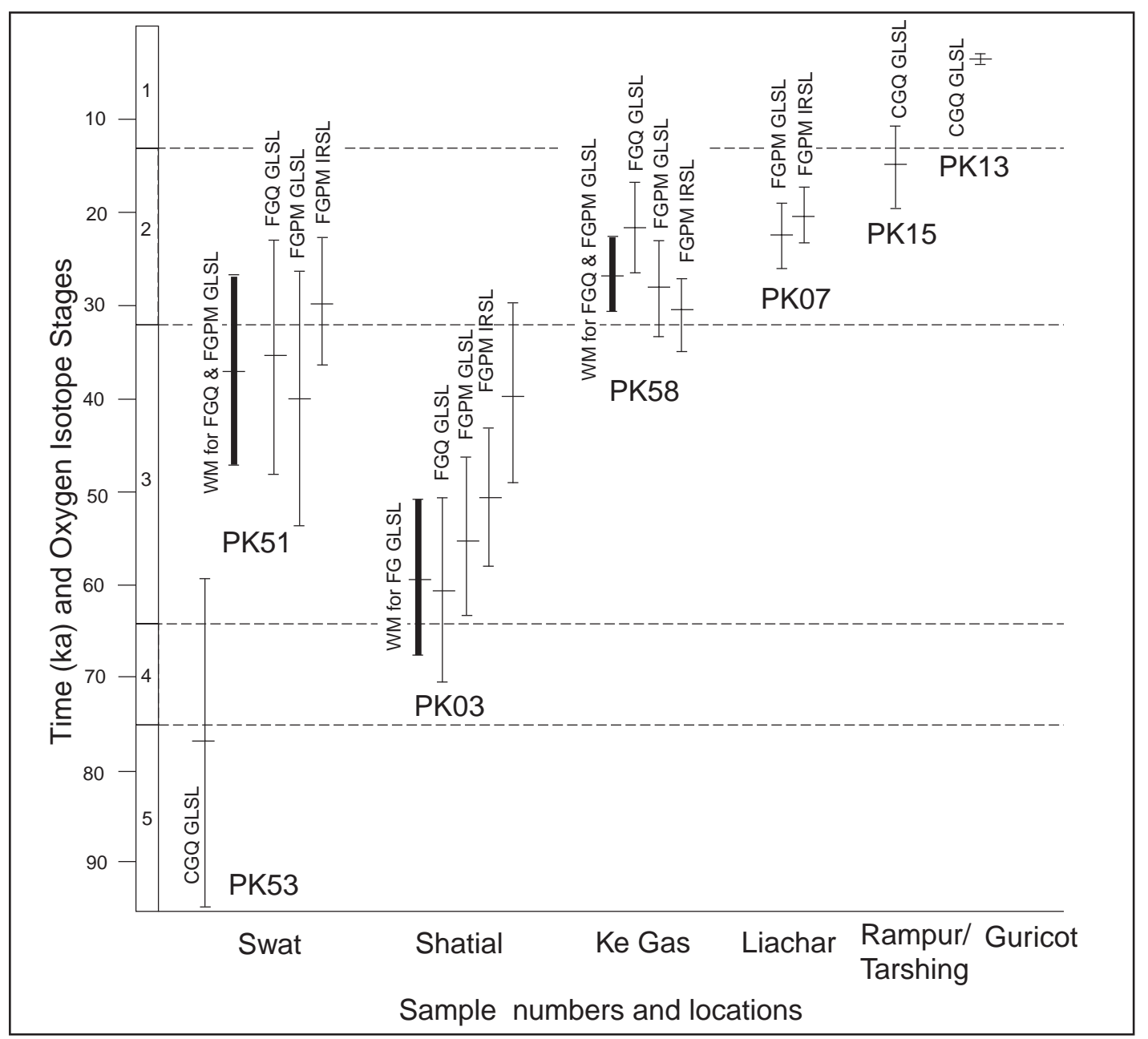

Figure 10 Graph summarising the OSL dates presented in this paper. FGQ = fine grained quartz; FGPM = fine grained polymineralic; $\mathrm{CGQ}=$ coarse grained quartz; GLSL = green light stimulated luminescence; IRSL = infrared stimulated luminescence; WM = weighted mean.

valley are clearly far younger than the moraines themselves. This reiterates Owen etal.'s (1992) warning regarding the need for careful sampling and selection of samples that represent that actual age of the glaciation that is being dated.

The OSL dates on the Jalipur Tillite at Ke Gas shows unequivocally that it is not the oldest till in the Himalayas as suggested by Shroder et al. (1989). Rather it supports Owen's $(1988,1989)$ view that the overconsolidation and partial lithification of the Jalipur Tillite was the result of glaciotectonism.

The young date (PK13, $3.3 \pm 0.58 \mathrm{ka})$ on the lacustrine deposits at Guricot may be easily explained if the lacustrine sediments were deposited in a lake that formed as a result of a landslide dam. It is unlikely that this date has any glacial significance.

Figure 11 shows the relative chronologies and new OSL dates for Swat and the middle Indus valley. These are compared with chronologies for other Himalayan regions. This dating helps confirm the view of Benn and Owen (1998) that glaciation at the western end of the Himalayas was asynchronous with the maximum extent of Northern Hemisphere ice sheets, i.e. the Last Glacial Maximum in Oxygen Isotope Stage 2. In support of this view, the maximum extents of glaciation in the Garhwal and Lahul Himalayas in India have been dated at ca. $63 \mathrm{ka}$, and before ca. 36-43 ka, respectively (Sharma and Owen, 1996; Owen et al., 1997). These are during Oxygen Isotope Stage 3, although the Garhwal date is at the very earliest part of the oxygen isotope stage. Furthermore, there is growing evidence that glaciation throughout the Himalayas may even be asynchronous between regions. In the Khumbu Himalaya, Richards (1999) have shown that the most extensive glacial advance during the last glacial cycle occurred in Oxygen Isotope Stage 2, ca. 18-25 ka.

The asynchroneity of glacial events in the Himalaya appears to reflect differences in climatic forcing mechanisms across the region (Benn and Owen, 1998). In the Pakistani Himalayas, the glaciations in Oxygen Isotope Stage 3 were probably coincident with a strengthened and/or a northward extension of the South Asian summer monsoon (cf. Clemens et al., 1991; Emeis et al., 1995). This suggests that the primary control on glacier expansion was enhanced summer snowfall at high altitudes. During Oxygen Isotope Stage 2, the Pakistani Himalayas would have experienced reduced summer precipitation, which would have restricted glacier accumulation despite cooler temperatures. In contrast, the maximum advance of glaciers in the Khumbu Himal occurred during Oxygen Isotope Stage 2 (18-25 ka). Richards (1999) argue that multiproxy data from the Arabian Sea (Sirocko et al., 1991) show that during the period 27-15 ka, low-level summer monsoon winds were predominantly westsouthwesterlies, rather than the present southwesterlies. The monsoon influence therefore would have extended further eastward, but would be less to the north and west than at present. This implies that the western Himalayas would have experienced less summer precipitation as compared with the 


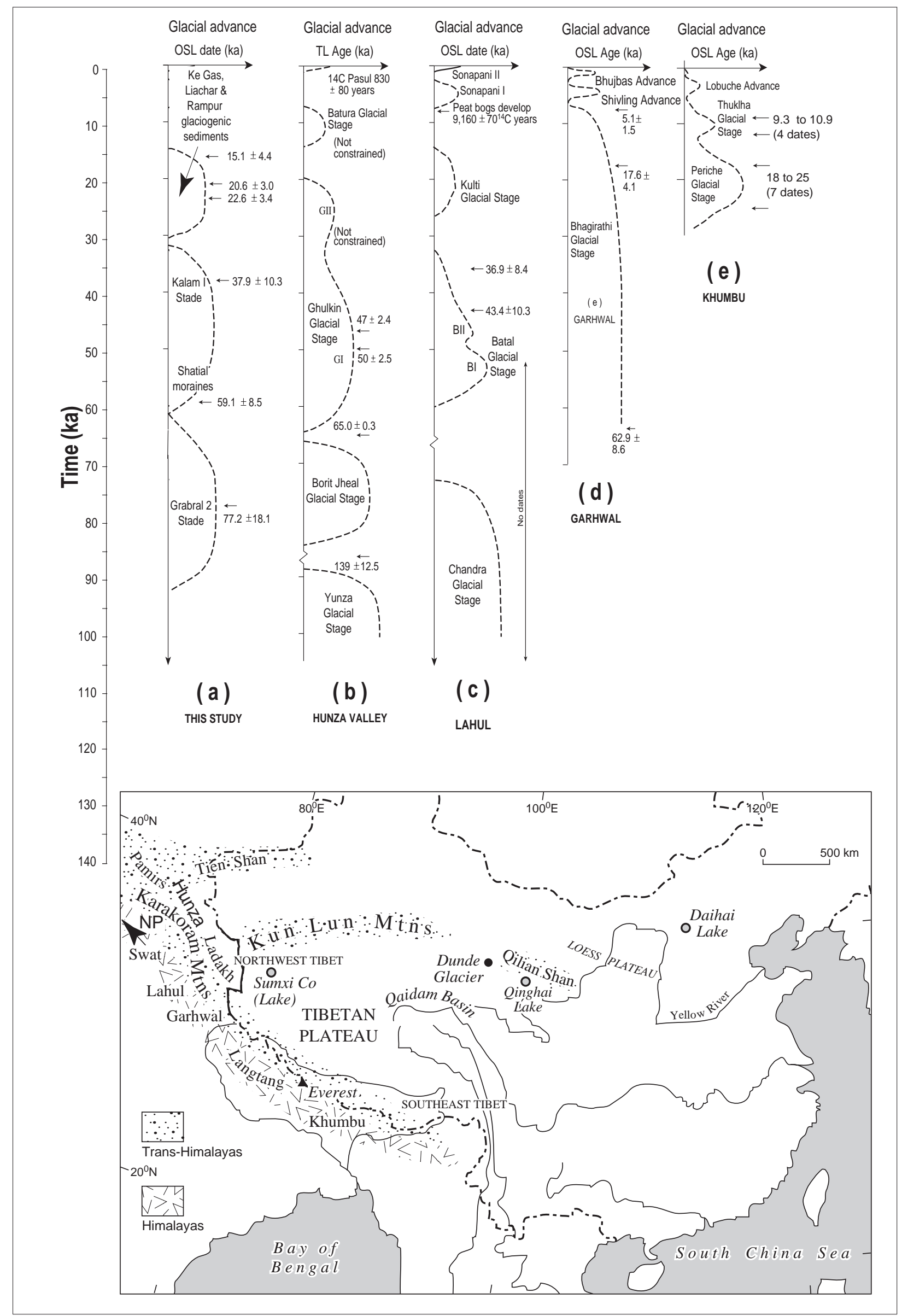

Figure 11 Relative chronologies and new OSL dates for glaciations in Northern Pakistan. (a) This study, summarising the OSL dates and relative chronologies for northern Pakistan; (b) Hunza valley after Derbyshire et al. (1984); (c) Lahul Himalaya after Owen et al. (1997); Garhwal Himalaya after Sharma and Owen (1996); (e) Khumbu Himal after Richards (1999). NP = Nanga Parbat. 
central and eastern Himalayas at that time. This would cause the glaciers in the eastern and central Himalayas to advance, whereas those in the western Himalayas would become less extensive during Oxygen Isotope Stage 2.

Although these OSL dates show that a series of moraines formed during Oxygen Isotope Stage 3 in the Swat and Indus valleys, it is not possible to resolve, particularly because of the large dating errors, whether these represent one or two separate glaciations. Clearly, further detailed mapping, morphostratigraphy and absolute dating is needed to constrain the timing of glaciation in northern Pakistan. Nevertheless, this study provides a geochronological framework for the future study of the Quaternary glacial history of northern Pakistan.

\section{References}

Aitken MJ, Xie J. 1992. Optical dating using infrared diodes: young samples. Quaternary Science Reviews 11: 147-152.

Benn D, Owen LA. 1998. The role of the Indian summer monsoon and the mid-latitude westerlies in Himalayan glaciation: review and speculative discussion. Journal of the Geological Society of London 155(2): 353-363.

Clemens S, Prell W, Murray D, Shimmeld G, Weedon G. 1991. Forcing mechanisms of the Indian Ocean monsoon. Nature 353 : 720-725.

Derbyshire E, Li Jijun, Perrott FA, Xu S, Waters RS. 1984. Quaternary glacial history of the Hunza Valley, Karakoram mountains, Pakistan. In The International Karakoram Project, Vol. 2, Miller K J (ed.). Cambridge University Press: Cambridge; 456-495.

Derbyshire E, Owen LA. 1997. Quaternary glacial history of the Karakoram Mountains and Northwest Himalayas: A Review. Quaternary Interational 38/39: 85-102.

Emeis K-C, Anderson DM, Doose H, Kroon D, Schulz-Bull D. 1995. Sea-surface temperatures and the history of monsoon upwelling in the Northwest Arabian Sea during the last 500 000 years. Quaternary Research 43: 355-361.

Finsterwalder R. 1935. The scientific work of the German Himalayan expedition to Nanga Parbat, 1934. Himalayan Journal 7 44-52.

Finsterwalder R. 1937. Die Gletscher des Nanga Parbat: Glaziologische Arbeiten der Deutschen Himalaya-Expedition 1934 und ihre Ergebnisse. Zeitschrift fur Gletscherkunde 25: 57-108.

Haserodt K. 1989. Zur pleistozänen und postglazialen Vergletscherung zwischen Hindukusch, Karakorum und Westhimalaya. In: Hochgebirgsräume Nordpakistans im Hindukusch, Karakorum und Westhimalaya (K. Haserodt, ed.), Beiträge und Materialen zur Regionalen Geographie, 2: 182-233. Institut für Geographie der Technischen Universität, Berlin.

Hewitt K. 1989. The altitudinal organzation of Karakoram geomorphic processes and depositional environment. Zeitscrift fur Geomorphologie 76: 9-32.

Kick W. 1986. Glacier mapping for an inventory of the Indus drainage basin: current state and future possibilities. Annals of Glaciology 8: 102-105.

Kuhle M. 1986. Former glacial stages in the mountain areas surrounding Tibet. In Nepal Himalaya, Geo-ecological Perspectives, Joshi S C (ed.). 437-473.

Kuhle M. 1996. Die Entstehung von Eiszeiten als Folge der Hebung eines subtropischen Hochlandes uber die Schneegrenze-dargestellt am Beispiel Tibers. Aufschluss 47: 145-164.

Kuhle M. 1997. New findings concerning the Ice Age (Last Glacial Maximum) glacier cover of the East-Pamir, of the Nanga Parbat up to the Central Himalaya and of Tibet, as well as the age of the Tibetan Inland Ice. GeoJournal 42: 87-257.
Kuhle M. 1998. Reconstruction of the 2.4 million $\mathrm{km}^{2}$ late Pleistocene Ice Sheet on the Tibetan Plateau and its impact on the global climate. Quaternary International 45/46: 71-108; Erratum 47/48: 173-182.

Misch P. 1935. Ein gefalterer junger Sandstein im Nordwest-Himalaya und sein Gefuge. Festschrift zum 60 geburstag von Hans Stille, Verlag, Stuttgart.

Owen LA. 1988. Terraces, uplift and climate in the Karakoram Mountains, Northern Pakistan. Unpublished PhD thesis, University of Leicester; 399 pp.

Owen LA. 1989. Neotectonics and glacial deformation in the Karakoram Mountains, Northern Pakistan. Tectonophysics 163: 227-265.

Owen LA. 1994. Glacial and non-glacial diamictons in the Karakoram Mountains. In The Deposition and Deformation of Tills, Croots D, Warren W (eds). A.A. Balkema: Rotterdam; 9-29.

Owen LA, Derbyshire E. 1989. The Karakoram glacial depositional system. Zeitscrift fur Geomorphologie, Supplemental Band 76: 33-73.

Owen LA, White BJ, Rendell H, Derbyshire E. 1992. Loessic silt deposits in the western Himalayas: their sedimentology, genesis and age. Catena 19: 493-509.

Owen LA, Mitchell W, Lehmkuhl F, Bailey RM, Coxon P, Rhodes EJ. 1997. Style and timing of Glaciation in the Lahul Himalaya, northern India. Journal of Quaternary Science 12: 83-110.

Owen LA, Scott CH, Derbyshire E. 2000. The Quaternay Glacial History of Nanga Parbat. Quaternary International, in press.

Porter SC. 1970. Quaternary glacial record in Swat Kohistan, West Pakistan. Geological Society of America Bulletin 81: 1421-1446.

Prescott JR, Hutton JT. 1994. Cosmic ray contributions to dose rates for luminescence and ESR dating: large depths and long-term time variations. Radiation Measurements 23: 497-500.

Rees-Jones J. 1995. Optical dating of young sediments using finegrain quartz. Ancient TL 13(2): 9-14.

Rhodes EJ. 1988. Methodological considerations in the optical dating of quartz. Quaternary Science Reviews 7: 395-400.

Rhodes EJ, Bailey RM. 1997. Thermal transfer effects observed in the luminescence of quartz from recent glacio-fluvial sediments. Quaternary Geochronology (Quaternary Science Reviews) 16: 291-298.

Richards BWM. 1999. Palaeoclimates of South Asia over the last $80 \mathrm{ka}$ : luminescence ages of sediments from former glaciations in Nepal and Pakistan. Unpublished Ph.D. thesis, Royal Holloway, University of London, 269 pp.

Scott $\mathrm{CH}$. 1992. Contemporary sediment transfer in the Himalayan glacial system: Implication for the interpretation of the Quaternary record. Unpublished PhD thesis, University of Leicester; 352 pp.

Sharma MC, Owen LA. 1996. Quaternary glacial history of the Garhwal Himalaya, India. Quaternary Science Reviews 15: 335-365.

Shroder JF, Khan MS, Lawrence RD, Madin IP, Higgins SM. 1989. Quaternary glacial chronology and neotectonics in the Himalaya of northern Pakistan. Geological Society of America Special Paper 232: $275-294$.

Shroder JF, Owen LA, Derbyshire E. 1993. Quaternary glaciation of the Karakoram and Nanga Parbat Himalaya. In Himalaya to the Sea: Geology, Geomorphology and the Quaternary, Shroder J F (ed.). Routledge: London; 132-158.

Sirocko F, Sarnthein M, Lange H, Erlenkeuser H. 1991. The atmospheric summer circulation and coastal upwelling in the Arabian Sea during the Holocene and the last glaciation. Quaternary Research 36: 72-93.

Sloan V, Phillips WM, Shroder JF, Sharma P, Rendell H. 1998. Asynchronous maximum advances of mountain glaciers in the Pakistan Himalaya. Geological Society of America, Abstracts with Programs 30(7): A-229.

Zimmerman DW. 1967. Thermoluminescence from fine grains from ancient pottery. Archaeometry 10: 26-28.

Zimmerman DW. 1971. Thermoluminescence dating using fine grains from ancient pottery. Archaeometry 13: 29-52. 